Check for updates

Cite this: RSC Adv., 2018, 8, 30071

Received 4th July 2018

Accepted 6th August 2018

DOI: 10.1039/c8ra05702h

rsc.li/rsc-advances

\section{TfOH mediated intermolecular electrocyclization for the synthesis of pyrazolines and its application in alkaloid synthesis $\uparrow$}

\author{
Sesuraj Babiola Annes, Pothiappan Vairaprakash (D) * and Subburethinam Ramesh (D) * \\ $\mathrm{TfOH}$ mediated easy access to interesting pyrazolines starting from an aldehyde, phenylhydrazine and \\ styrene has been developed. The scope of this synthetic methodology has been explored by \\ synthesizing various 1,3,5-trisubstituted pyrazolines in very good yields with very high regioselectivity. \\ The origin of regioselectivity has been explained by comparing the stability of possible intermediate \\ carbocations. The synthetic utility of a green solvent has been explored by synthesizing some of \\ pyrazolines in a DES medium. The synthetic application of the present methodology is employed in the \\ synthesis of a pyrazoline alkaloid.
}

Pyrazoles and pyrazolines are known to exhibit interesting biological and photo-physical behaviours. The biological activities of pyrazoles/pyrazolines have been discussed in several reviews. ${ }^{1-4}$ A few representative examples of biologically and medicinally important pyrazoles and pyrazolines are given in Fig. $1 .^{5-7}$ In particular, considerable interest has been focused on 1,3,5-trisubstituted pyrazoline derivatives due their potential pharmacological activities including (i) antitubercular activity against the $\mathrm{H} 37 \mathrm{Rv}$ strain of Mycobacterium, ${ }^{9}$ (ii) antiproliferative activity, ${ }^{\mathbf{8} 10}$ (iii) antibacterial activity, ${ }^{11-13}$ (iv) antiobesity effect in an animal model of the potent cannabinoid CB1 receptor antagonist, ${ }^{14}$ (v) pre-emergent herbicide activity against various kinds of weeds, ${ }^{15}$ and (vi) ACE-inhibitory activity with $0.123 \mathrm{mM}$ IC504. ${ }^{16}$ Pyrazoline derivatives show enhanced biological activity compared with their corresponding pyrazoles. ${ }^{17}$ In addition, the pyrazoline motif is known to exhibit photo-luminescent behaviour due to intra-molecular charge transfer (ICT) in the excited state and also shows hole transport behaviour. ${ }^{18-24}$

Various synthetic approaches have been developed to access these biologically important 1,3,5-trisubstituted pyrazoline/ pyrazole compounds. ${ }^{25-28}$ The most general synthetic approach proceeding via a reaction of 1,3-dicarbonyl compounds with arylhydrazines results in poor regioselectivity. ${ }^{3,29,30}$ A synthetic method which employs appropriate chalcones and arylhydrazines has been considered to be the most widely accepted

Department of Chemistry, School of Chemical and Biotechnology, SASTRA Deemed University, Thanjavur, Tamil Nadu, India. E-mail: vairaprakash@scbt.sastra.edu; ramesh_s@scbt.sastra.edu; Fax: +91-4362-264120; Tel: +91-4362-264101-3614; +914362-264101-3791

$\dagger$ Electronic supplementary information (ESI) available: Experimental details, supporting data and NMR spectra $\left({ }^{1} \mathrm{H}\right.$ and $\left.{ }^{13} \mathrm{C}\right)$ are provided. See DOI: 10.1039/c8ra05702h method for accessing pyrazolines, but this method falls behind due to a greater number of synthetic steps involved..$^{31-34}$ Recently Wang et al. disclosed a methodology proceeding via

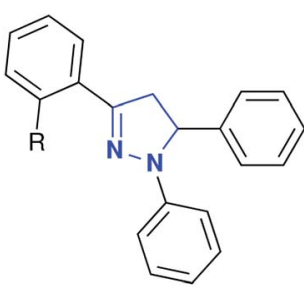

$\boldsymbol{R}=\boldsymbol{H}$ or $\mathrm{OH}$, antibacterial

Ar

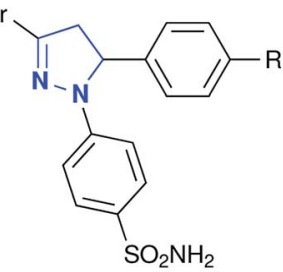

Ar = 3,5-dimethoxypheny $\mathrm{R}=\mathrm{OMe}$ or $\mathrm{NMe}_{2}$ anti-inflammatory<smiles>C(=C/c1ccccc1)\C1=NN(c2ccccc2)C(c2ccccc2)C1</smiles>

Alkaloid isolated from Aerial Parts of Euphorbia guyoniana

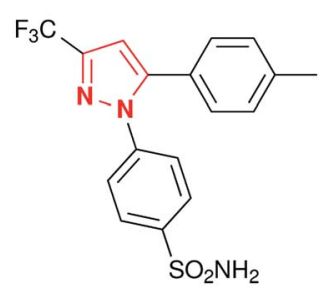

Celecoxib<smiles>NS(=O)(=O)c1ccc(-n2nc(C(F)(F)F)cc2-c2ccc(F)cc2)cc1</smiles>

Mavacoxib

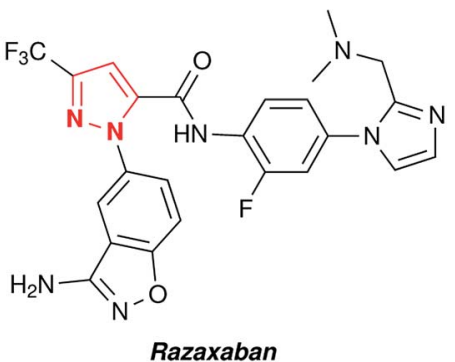

Fig. 1 Representative examples of medicinally important 1,3,5trisubstituted pyrazolines and pyrazoles. 
a three component $[3+2]$ cycloaddition using $20 \mathrm{~mol} \%$ $\mathrm{Cu}(\mathrm{OTf})_{2}$ at elevated temperature. ${ }^{35}$ The development of synthetic methodology to prepare active pharmaceutical ingredients (APIs) would preferably involve (i) high regioselectivity, (ii) diversity in substrates, (iii) the least number of synthetic steps involved and (iv) attaining target compounds, free of metal traces. Hence, a regioselective tandem one-pot intermolecular electrocyclization reaction under metal free condition to access 1,3,5-trisubstituted pyrazolines would be of great importance.

In this regard, we are disclosing a general, metal free and green synthetic methodology to access diverse pyrazoline derivatives with various functionalities including $-\mathrm{NO}_{2},-\mathrm{OH}$ and aliphatic groups using arylhydrazines, aldehydes and styrenes. We have obtained the corresponding pyrazoline products in very good yields with enhanced regioselectivity. In addition, we have employed this synthetic methodology in the synthesis of a pyrazoline alkaloid (1,5-diphenyl-3-styryl-2pyrazoline).

In our initial studies to attempt metal free conditions, iodine mediated intermolecular electrocyclization of tolualdehyde 1a, phenylhydrazine $\mathbf{2 a}$ and styrene $\mathbf{3}$ was explored (Table $\mathbf{1}$ ). The use of a substoichiometric amount of iodine ( 0.2 equiv.) yielded the corresponding pyrazoline $\mathbf{4 a}$ in $25 \%$ yield (Table 1 , entry 1 ). Increasing the amount of iodine did not result in considerable

Table 1 Optimization of reaction conditions in the synthesis of pyrazoline $4 a^{a}$

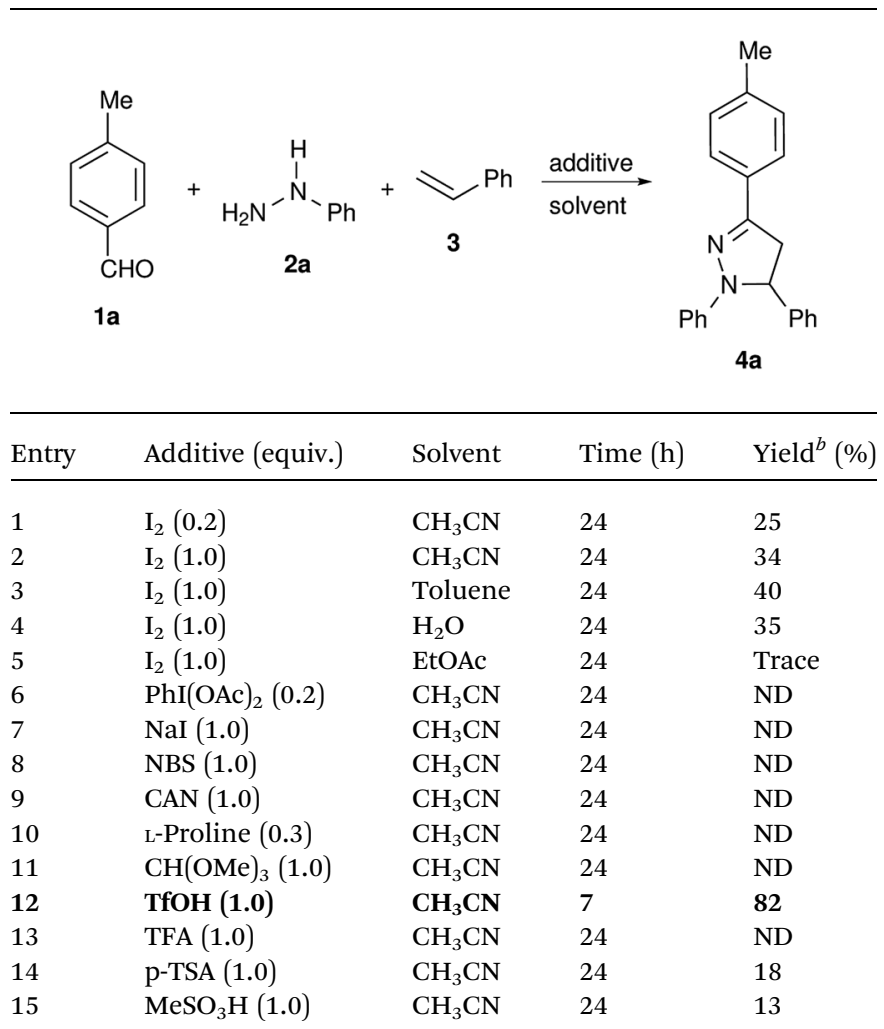

${ }^{a}$ A solution of tolualdehyde $1 \mathrm{a}(1.0 \mathrm{mmol})$ and phenylhydrazine $\mathbf{2 a}(1.0$ $\mathrm{mmol})$ in solvent $(1.0 \mathrm{~mL})$ was treated with additive followed by styrene $3(1.0 \mathrm{mmol})$ and stirred. ${ }^{b}$ Isolated yield; ND = not detected. enhancement of the yield (Table 1, entries 1-5). Due to it being less hazardous among the screened solvents, acetonitrile was used as a solvent for further screening of other non-metal catalysts including TfOH, PhIOAc, NaI, NBS, CAN, L-proline, $\mathrm{CH}(\mathrm{OMe})_{3}$, TFA, p-TSA and $\mathrm{MeSO}_{3} \mathrm{H}$ (Table 1, entries 6-13). $\mathrm{TfOH}$ was found to be the most effective in mediating electrocyclization and pyrazoline 4 a was obtained in $82 \%$ yield (Table 1 , entry 12). It is presumed that $\mathrm{TfOH}$ alone is capable of forming an intermediate carbocation $\mathbf{I}-\mathbf{1}$ via hydride abstraction from hydrazone by the superacid species $\mathrm{TfOH}_{2}{ }^{+}$(Scheme 1). ${ }^{36,37}$ The use of other solvents such as $\mathrm{H}_{2} \mathrm{O}$, DMF, DMSO and ethanol did not result in product formation, as $\mathrm{TfOH}$ might be deactivated by these solvents (see ESI, Table S1 $\dagger$ ).

We have observed very good regioselectivity in the formation of pyrazolines mediated by $\mathrm{TfOH}$. Mechanistically, the carbocation I-1 can interact with either of the alkenyl carbons in styrene resulting in two types of cationic intermediates: (i) the most stable benzylic carbocation I-2 and (ii) the least stable primary carbocation I-3. The stability of the benzylic carbocation I-2 over the primary carbocation I-3 directs the reaction pathway towards the formation of a 5-phenyl substituted product 4a over a 4-phenyl substituted product 5a (Scheme 1).

The scope of this synthetic methodology has been studied by varying the substrates. Both aromatic and aliphatic aldehydes reacted well under the reaction conditions and their corresponding pyrazolines were obtained in yields of up to $86 \%$

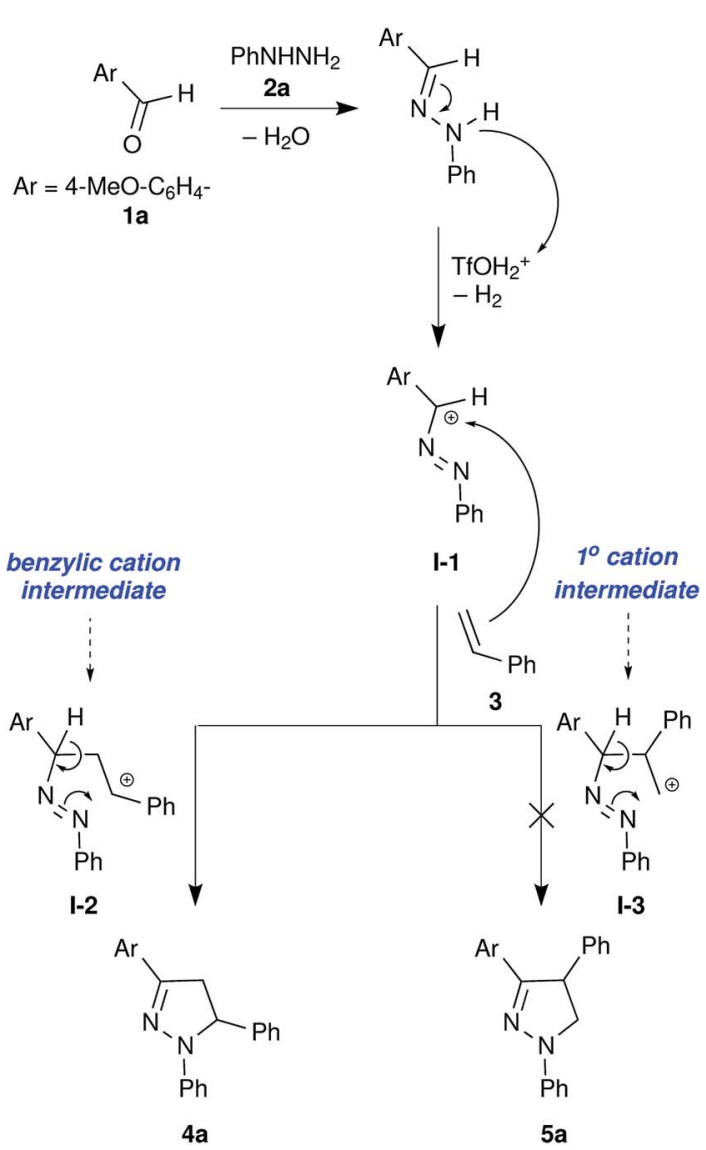

Scheme 1 Origin of regioselectivity in the formation of pyrazoline $4 a$. 
Table 2 Synthesis of various pyrazolines $4 a-m^{a}$

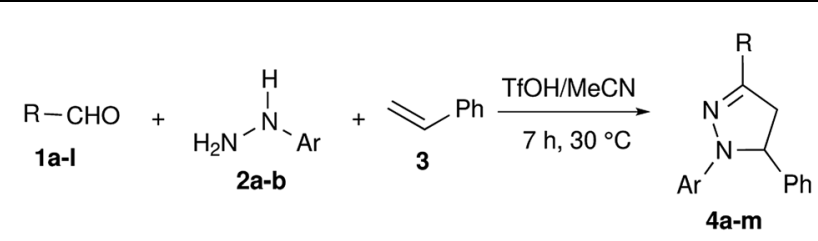

\begin{tabular}{|c|c|c|c|c|}
\hline Entry & $\mathrm{R}=$ & $\mathrm{Ar}=$ & Product & Yield $^{b}(\%)$ \\
\hline 1 & $4-\mathrm{Me}-\mathrm{C}_{6} \mathrm{H}_{4}-1 \mathrm{a}$ & $\mathrm{C}_{6} \mathrm{H}_{5}-2 \mathrm{a}$ & $4 a$ & 82 \\
\hline 2 & $4-\mathrm{MeO}-\mathrm{C}_{6} \mathrm{H}_{4}-\mathbf{1 b}$ & $\mathrm{C}_{6} \mathrm{H}_{5}-2 \mathrm{a}$ & $4 b$ & 73 \\
\hline 3 & $3-\mathrm{MeO}-\mathrm{C}_{6} \mathrm{H}_{4}-1 \mathrm{c}$ & $\mathrm{C}_{6} \mathrm{H}_{5}-2 \mathrm{a}$ & $4 c$ & 57 \\
\hline 4 & $\mathrm{C}_{6} \mathrm{H}_{5^{-}}-1 \mathrm{~d}$ & $\mathrm{C}_{6} \mathrm{H}_{5}-2 \mathrm{a}$ & $4 d$ & 63 \\
\hline 5 & $4-\mathrm{Br}-\mathrm{C}_{6} \mathrm{H}_{4}-1 \mathrm{e}$ & $\mathrm{C}_{6} \mathrm{H}_{5}-2 \mathrm{a}$ & $4 e$ & 61 \\
\hline 6 & $4-\mathrm{Cl}-\mathrm{C}_{6} \mathrm{H}_{4}-\mathbf{1 f}$ & $\mathrm{C}_{6} \mathrm{H}_{5}-2 \mathrm{a}$ & 4f & 58 \\
\hline 7 & $4-\mathrm{F}-\mathrm{C}_{6} \mathrm{H}_{4}-1 \mathrm{~g}$ & $\mathrm{C}_{6} \mathrm{H}_{5}-2 \mathrm{a}$ & $4 \mathrm{~g}$ & 39 \\
\hline 8 & $4-\mathrm{NO}_{2}-\mathrm{C}_{6} \mathrm{H}_{4}-\mathbf{1 h}$ & $\mathrm{C}_{6} \mathrm{H}_{5}-2 \mathrm{a}$ & $4 \mathrm{~h}$ & 24 \\
\hline 9 & $2-\mathrm{NO}_{2}-\mathrm{C}_{6} \mathrm{H}_{4}-1 \mathbf{i}$ & $\mathrm{C}_{6} \mathrm{H}_{5}-2 \mathrm{a}$ & $4 \mathrm{i}$ & 45 \\
\hline 10 & $2-\mathrm{HO}-\mathrm{C}_{6} \mathrm{H}_{4}-\mathbf{1 j}$ & $\mathrm{C}_{6} \mathrm{H}_{5}-2 \mathrm{a}$ & $4 j$ & 82 \\
\hline 11 & $\mathrm{CH}_{3} \mathrm{CH}_{2} \mathrm{CH}_{2}-1 \mathrm{k}$ & $\mathrm{C}_{6} \mathrm{H}_{5}-2 \mathrm{a}$ & $4 k$ & 86 \\
\hline 12 & $\left(\mathrm{CH}_{3}\right)_{2} \mathrm{CH}-1 \mathrm{l}$ & $\mathrm{C}_{6} \mathrm{H}_{5}-2 \mathrm{a}$ & 41 & 58 \\
\hline 13 & $4-\mathrm{Me}-\mathrm{C}_{6} \mathrm{H}_{4}-\mathbf{1 a}$ & $4-\mathrm{Me}-\mathrm{C}_{6} \mathrm{H}_{4}-2 \mathbf{b}$ & $4 \mathrm{~m}$ & 82 \\
\hline
\end{tabular}

${ }^{a}$ A solution of aldehyde $\mathbf{1 a}-\mathbf{l}(1.0 \mathrm{mmol})$ and arylhydrazine $2 \mathrm{a}, \mathbf{2 b}(1.0$ mmol) in $\mathrm{CH}_{3} \mathrm{CN}(1.0 \mathrm{~mL})$ was treated with $\mathrm{TfOH}$ followed by styrene $3(1.0 \mathrm{mmol})$ and stirred. ${ }^{b}$ Isolated yield.

(Table 2). The yields were in accordance with the stability of the corresponding benzylic cations I-1. In the reactions employing aromatic aldehydes with electron donating groups, pyrazolines were obtained in very good yields (Table 2, entries 1 and 2), as I1 might receive additional stability from electron donating substituents. The methoxy group in the meta position did not play a considerable role in stabilizing the benzylic carbocation I$\mathbf{1}$, hence the yield of the corresponding pyrazoline $4 \mathbf{c}$ was moderate (Table 2, entry 3). Analogous to this, products were obtained in moderate yields for aldehydes with halogen substitution $(\mathrm{Cl}$ and $\mathrm{Br})$ and without any substitution, as there is neutrality between the electron withdrawing effect through -I and the electron releasing effect through $+\mathrm{R}$ in $\mathrm{H} / \mathrm{Cl} / \mathrm{Br}-$ substituted aldehydes (2, entries 4-6). The high electronegativity of fluorine destabilizes I-1, hence its corresponding pyrazoline $\mathbf{4 g}$ was obtained in low yield (Table 2, entry 7). Similarly,

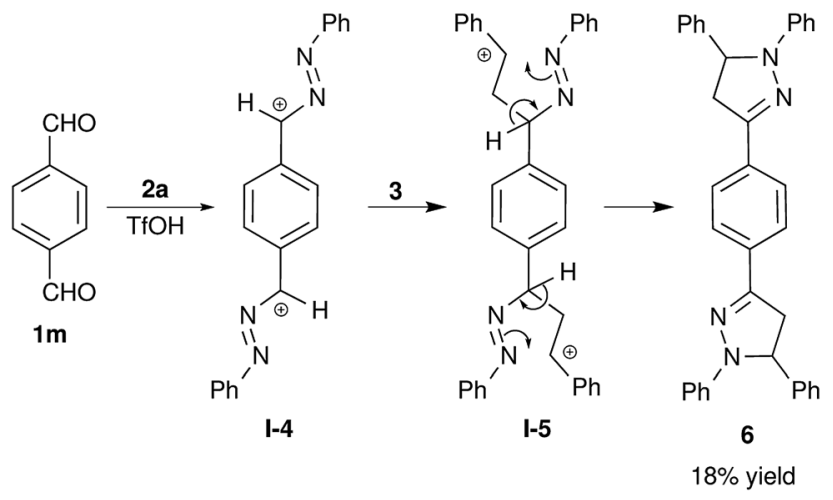

Scheme 2 Synthesis of bis-pyrazoline 7 from terephthalaldehyde. pyrazolines $4 \mathbf{h}$ and $4 \mathbf{i}$ were obtained in poor yields due to the strong electron withdrawing effect of the $-\mathrm{NO}_{2}$ group via $-\mathrm{I}$ and $-\mathrm{R}$ (Table 2, entries 8 and 9). In every case, the obtained regioselectivity was very high and benzylic cation intermediate I-2 derived compounds were obtained as the only products.

Using this methodology, we have attempted the synthesis of bis-pyrazoline 6 from terephthalaldehyde $\mathbf{1 m}$. The bispyrazoline 6 was obtained in very low yield, which is also in accordance with the proposed mechanism depicted in Scheme 1. The formation bis-pyrazoline 6 was expected to proceed via a bis-benzylic cation I-4 (Scheme 2), which is highly destabilized by conjugation between two cationic sites. Thus, formation of the bis-benzylic cation I-4 is less probable and resulted in the observed poor yield of bis-pyrazoline $6(18 \%)$ even after $48 \mathrm{~h}$ of reaction time. Bis-pyrazoline 6 was structurally characterized by NMR spectroscopy and high resolution mass spectrometry (HRMS) analysis.

We wanted to apply this synthetic methodology in the synthesis of a pyrazoline alkaloid. Many species of the genus Euphorbia are medicinally important and known to treat various ailments including gonorrhea, skin diseases, gastrointestinal disorders, migraines and anaphylaxis. ${ }^{38-41}$ Alkaloid 7 (1,5-diphenyl-3-styryl-2-pyrazoline) was isolated from aerial

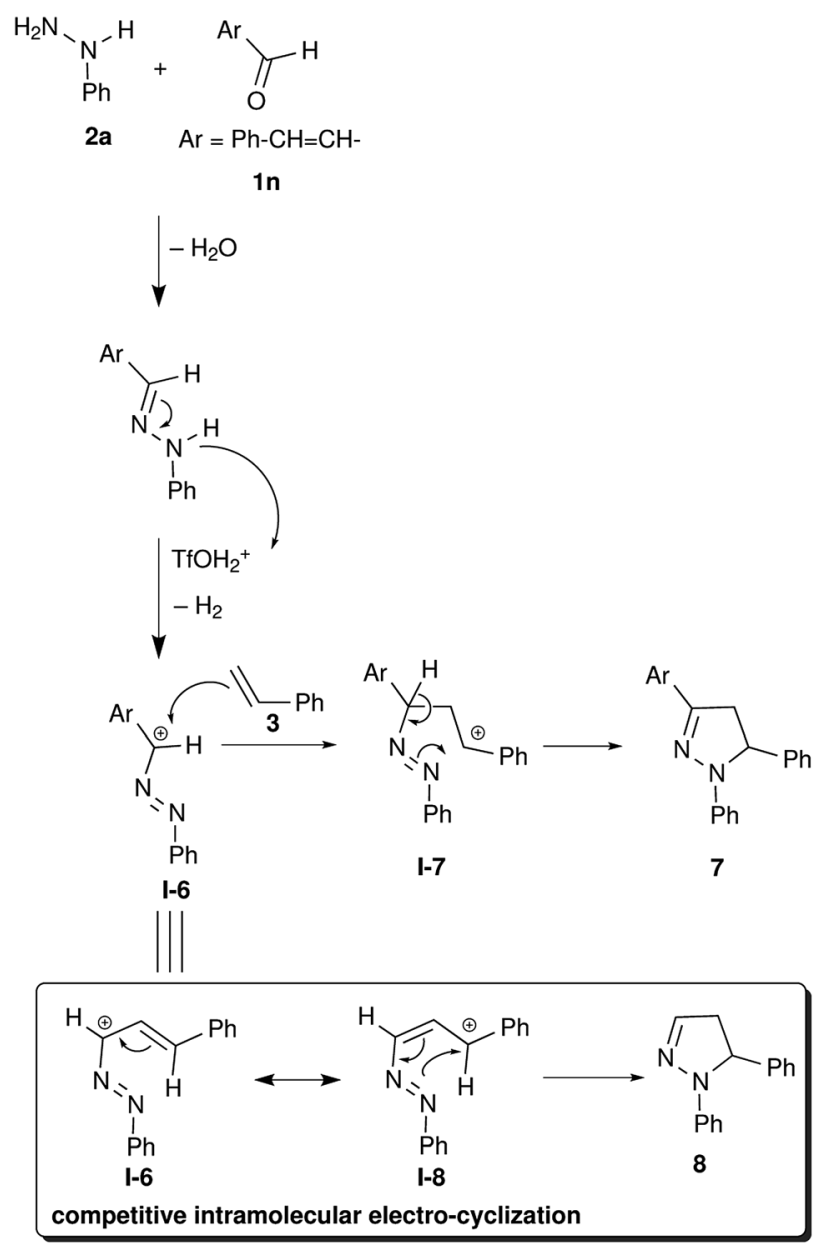

Scheme 3 Application in alkaloid synthesis: synthesis of alkaloid 7. 
Table 3 Synthesis of various pyrazolines in DES media ${ }^{a}$

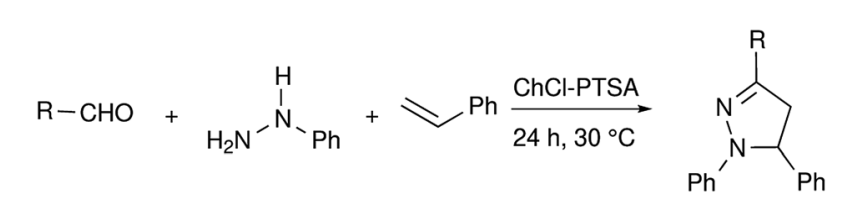

\begin{tabular}{lllll}
\hline Entry & $\mathrm{R}=$ & $\mathrm{Ar}=$ & Product & Yield $^{b}(\%)$ \\
\hline 1 & $4-\mathrm{Me}-\mathrm{C}_{6} \mathrm{H}_{4}-\mathbf{1 a}$ & $\mathrm{C}_{6} \mathrm{H}_{5}-\mathbf{2 a}$ & $\mathbf{4 a}$ & 45 \\
2 & $2-\mathrm{HO}_{-} \mathrm{C}_{6} \mathrm{H}_{4}-\mathbf{1 j}$ & $\mathrm{C}_{6} \mathrm{H}_{5}-\mathbf{2 a}$ & $\mathbf{4 j}$ & 61 \\
3 & $\mathrm{CH}_{3} \mathrm{CH}_{2} \mathrm{CH}_{2}-\mathbf{1 k}$ & $\mathrm{C}_{6} \mathrm{H}_{5}-\mathbf{2 a}$ & $\mathbf{4 k}$ & 45 \\
4 & $\mathrm{C}_{6} \mathrm{H}_{5}-\mathrm{CH}=\mathrm{CH}-\mathbf{1 n}$ & $4-\mathrm{Me}-\mathrm{C}_{6} \mathrm{H}_{4}-\mathbf{2 b}$ & Alkaloid 7 & 54
\end{tabular}

${ }^{a}$ A mixture of aldehyde $(1.0 \mathrm{mmol})$ arylhydrazine $(1.0 \mathrm{mmol})$ and styrene $(1 \mathrm{mmol})$ in DES $(1.0 \mathrm{~mL})$ stirred at $30{ }^{\circ} \mathrm{C}$ for $24 \mathrm{~h} .{ }^{b}$ Isolated yield.

parts of Euphorbia guyoniana. ${ }^{42}$ We have adopted TfOH mediated electrocyclization to access alkaloid 7 starting from cinnamaldehyde $\mathbf{1 n}$, phenylhydrazine $\mathbf{2 a}$ and styrene $\mathbf{3}$. In this reaction, the formation of pyrazole $\mathbf{8}$ via intramolecular electrocyclization is expected to compete with the formation of the desired alkaloid 7 via intermolecular electrocyclization (Scheme 3). Interestingly, the reaction with cinnamaldehyde did not undergo intramolecular cyclization and the required alkaloid 7 was obtained in $82 \%$ yield.

Recently, deep eutectic solvents (DES) have been used as green solvents in various applications. ${ }^{\mathbf{4 3 - 4 5}}$ We have explored the use of a few DES including the eutectic mixture of (i) ChCl: urea, (ii) ChCl: PTSA, (iii) $\mathrm{ChCl}: \mathrm{TfOH}$ and (iv) $\mathrm{ChCl}$ : glycol in our synthetic methodology to access trisubstituted pyrazolines (see ESI, Table S2 $\dagger$ ). The eutectic mixture $\mathrm{ChCl}$ : PTSA was found to be effective among the DES screened and corresponding 1,3,5-trisubstituted pyrazolines were obtained in yields of up to $61 \%$, without the use of any additives (Table 3). We believe that the $\mathrm{ChCl}$ : PTSA DES itself can induce the formation of intermediate I-1 to some extent and can result in the formation of pyrazolines, even in the absence of catalysts.

In conclusion, we have developed a metal free $\mathrm{TfOH}$ or DES mediated intermolecular electrocyclization of aldehydes, hydrazine and styrene to generate 1,3,5-trisubstituted pyrazolines. The observed very high regioselectivity of the reaction has been rationalized by the stability of the proposed benzylic cation intermediate. The substrate scope has been studied and various pyrazolines have been obtained in moderate to very good yields. The obtained yields were in accordance with the stability of the proposed intermediate carbocations obtained by the electronic effects of substitutions. Working towards greener synthesis, we have screened various deep eutectic mixtures as media for this transformation. The DES ChCl : PTSA was found to be effective in mediating pyrazoline formation and the corresponding pyrazolines were obtained in moderate yields in the absence of any other catalysts. The application of this synthetic methodology has been demonstrated in the synthesis of a natural product, alkaloid 7 obtained from aerial parts of Euphorbia guyoniana.

\section{Conflicts of interest}

There are no conflicts to declare.

\section{Acknowledgements}

S. R. sincerely thanks DST-SERB, the Government of India, New Delhi for financial support under the DST INSPIRE Faculty Program (Grant No. DST/INSPIRE/04-I/2017/000002). B. A. thanks SASTRA Deemed University for the research fellowship.

\section{References}

1 V. V. Salian, B. Narayana, B. K. Sarojini and K. Byrappa, Lett. Drug Des. Discovery, 2018, 15, 516-574.

2 A. Marella, M. R. Ali, M. T. Alam, R. Saha, O. Tanwar, M. Akhter, M. Shaquiquzzaman and M. M. Alam, Mini-Rev. Med. Chem., 2013, 13, 921-931.

3 S. Fustero, M. Sánchez-Roselló, P. Barrio and A. SimónFuentes, Chem. Rev., 2011, 111, 6984-7034.

4 S. Kumar, S. Bawa, S. Drabu, R. Kumar and H. Gupta, Recent Pat. Anti-Infect. Drug Discovery, 2009, 4, 154-163.

5 S. R. Cox, S. P. Lesman, J. F. Boucher, M. J. Krautmann, B. D. Hummel, M. Savides, S. Marsh, A. Fielder and M. R. Stegemann, J. Vet. Pharmacol. Ther., 2010, 33, 461-470. 6 D. Zhang, N. Raghavan, S.-Y. Chen, H. Zhang, M. Quan, L. Lecureux, L. M. Patrone, P. Y. S. Lam, S. J. Bonacorsi, R. M. Knabb, G. L. Skiles and K. He, Drug Metab. Dispos., 2007, 36, 303-315.

7 T. D. Penning, J. J. Talley, S. R. Bertenshaw, J. S. Carter, P. W. Collins, S. Docter, M. J. Graneto, L. F. Lee, J. W. Malecha, J. M. Miyashiro, R. S. Rogers, D. J. Rogier, S. S. Yu, G. D. Anderson, E. G. Burton, J. N. Cogburn, S. A. Gregory, C. M. Koboldt, W. E. Perkins, K. Seibert, A. W. Veenhuizen, Y. Y. Zhang and P. C. Isakson, J. Med. Chem., 1997, 40, 1347-1365.

8 P.-C. Lv, H.-Q. Li, J. Sun, Y. Zhou and H.-L. Zhu, Bioorg. Med. Chem., 2010, 18, 4606-4614.

9 S. G. Kini, A. R. Bhat, B. Bryant, J. S. Williamson and F. E. Dayan, Eur. J. Med. Chem., 2009, 44, 492-500.

10 F. M. Awadallah, G. A. Piazza, B. D. Gary, A. B. Keeton and J. C. Canzoneri, Eur. J. Med. Chem., 2013, 70, 273-279.

11 A. Setyawati, T. D. Wahyuningsih and B. Purwono, Asian J. Chem., 2017, 29, 454-456.

12 A. Ahmad, A. Husain, S. A. Khan, M. Mujeeb and A. Bhandari, J. Saudi Chem. Soc., 2016, 20, 577-584.

13 S. Kini and A. Gandhi, Indian J. Pharm. Sci., 2008, 70, 105. 14 A. Joharapurkar, S. Raval, J. Z. Patel, R. Soni, P. Raval, A. Gite, A. Goswami, N. Sadhwani, N. Gandhi, H. Patel, B. Mishra, M. Solanki, B. Pandey, M. R. Jain and P. R. Patel, J. Med. Chem., 2007, 50, 5951-5966.

15 N. Kudo, S. Furuta, M. Taniguchi, T. Endo and K. Sato, Chem. Pharm. Bull., 1999, 47, 857-868.

16 M. Bonesi, M. R. Loizzo, G. A. Statti, S. Michel, F. Tillequin and F. Menichini, Bioorg. Med. Chem., 2010, 20, 1990-1993. 
17 I. Rathish, K. Javed, S. Ahmad, S. Bano, M. Alam, K. Pillai, S. Singh and V. Bagchi, Bioorg. Med. Chem., 2009, 19, 255258.

18 A. Karuppusamy and P. Kannan, J. Lumin., 2018, 194, 718728.

19 E. Bozkurt, H. I. Gul and E. Mete, J. Photochem. Photobiol., A, 2018, 352, 35-42.

20 P. Kundu, D. Banerjee, G. Maiti and N. Chattopadhyay, Phys. Chem. Chem. Phys., 2017, 19, 11937-11946.

21 J. Ajantha, E. Varathan, V. Bharti, V. Subramanian, S. Easwaramoorthi and S. Chand, RSC Adv., 2016, 6, 786-795.

22 M. Jin, Y. J. Liang, R. Lu, X. H. Chuai, Z. H. Yi, Y. Zhao and H. J. Zhang, Synth. Met., 2004, 140, 37-41.

23 M. Wang, J. Zhang, J. Liu, C. Xu and H. Ju, J. Lumin., 2002, 99, 79-83.

24 X.-C. Gao, H. Cao, L.-Q. Zhang, B.-W. Zhang, Y. Cao and C.-H. Huang, J. Mater. Chem., 1999, 9, 1077-1080.

25 X. Wang, Y. Ming Pan, X. Chao Huang, Z. Yuan Mao and H. Shan Wang, Org. Biomol. Chem., 2014, 12, 2028-2032.

26 Y. Wu, H. Xie, J. Zhu, Z. Chen and S. Li, Synthesis, 2011, 2011, 2767-2774.

27 K. Alex, A. Tillack, N. Schwarz and M. Beller, Org. Lett., 2008, 10, 2377-2379.

28 M. S. M. Ahmed, K. Kobayashi and A. Mori, Org. Lett., 2005, 7, 4487-4489.

29 S. T. Heller and S. R. Natarajan, Org. Lett., 2006, 8, 26752678.

30 S. P. Singh, D. Kumar, H. Batra, R. Naithani, I. Rozas and J. Elguero, Can. J. Chem., 2000, 78, 1109-1120.

31 A. Kedjadja, A. Bouraiou and R. Merdes, Int. J. Org. Chem., 2018, 08, 105-114.
32 S. Qin, Y. Zheng, F.-G. Zhang and J.-A. Ma, Org. Lett., 2017, 19, 3406-3409.

33 A. Ciupa, P. A. D. Bank, M. F. Mahon, P. J. Wood and L. Caggiano, MedChemComm, 2013, 4, 956.

34 A. Voskienė and V. Mickevičius, Chem. Heterocycl. Compd., 2009, 45, 1485-1488.

35 Q. Wu, P. Liu, Y. Ming Pan, Y. Li Xu and H. Shan Wang, RSC Adv., 2012, 2, 10167.

36 J.-C. Culmann, M. Simon and J. Sommer, J. Chem. Soc., Chem. Commun., 1990, 1098.

37 M. Herlem, in Non-Aqueous Solutions-5, Elsevier, 1977, pp. 107-113.

38 C. Khare, Indian Medicinal Plants: An Illustrated Dictionary, Springer, 2012.

39 E. Barile, G. Corea and V. Lanzotti, Nat. Prod. Commun., 2008, 3, 1003-1020.

40 M. Youssouf, P. Kaiser, M. Tahir, G. Singh, S. Singh, V. Sharma, N. Satti, S. Haque and R. Johri, Fitoterapia, 2007, 78, 535-539.

41 A. K. Singla and K. Pathak, J. Ethnopharmacol., 1990, 29, 291294.

42 T. Boudiar, L. Hichem, A. Khalfallah, A. Kabouche, Z. Kabouche, I. Brouard, J. Bermejo and C. Bruneau, Nat. Prod. Commun., 2010, 5, 35-37.

43 D. A. Alonso, A. Baeza, R. Chinchilla, G. Guillena, I. M. Pastor and D. J. Ramón, Eur. J. Org. Chem., 2016, 612-632.

44 P. Liu, J.-W. Hao, L.-P. Mo and Z.-H. Zhang, RSC Adv., 2015, 5, 48675-48704.

45 E. L. Smith, A. P. Abbott and K. S. Ryder, Chem. Rev., 2014, 114, 11060-11082. 